\title{
Parasitism by argulids (Crustacea: Branchiura) in piranhas (Osteichthyes: Serrasalmidae) captured in the Caiçara bays, upper Paraguay River, Pantanal, Mato Grosso State, Brazil
}

\author{
Márcio Fontana ${ }^{1}$, Ricardo Massato Takemoto ${ }^{2}$, José Celso de Oliveira Malta ${ }^{3}$ and \\ Lúcia Aparecida de Fátima Mateus ${ }^{4}$
}

\begin{abstract}
In this study, 446 fishes were analyzed: 190 Pygocentrus nattereri, 193 Serrasalmus maculatus, and 63 S. marginatus. They were captured in two bays, upper and lower Caiçara, in the upper Paraguay River basin, during one hydrological cycle from May 2008 to April 2009. Six species of Branchiura were found: Dolops bidentata, D. longicauda, Dolops sp., Argulus multicolor, A. chicomendesi, and Dipteropeltis hirundo. All fish species were infested by more than one species of Branchiura and the overall prevalence was $33.4 \%$. The following prevalences were observed: $52.6 \%$ in P. nattereri; $20.3 \%$ in S. maculatus, and $15.8 \%$ in S. marginatus. The relative condition factor $(\mathrm{Kn})$ differed significantly between parasitized and non parasitized individuals only in P. nattereri and S. maculatus. There was no correlation between $\mathrm{Kn}$ and abundance of parasites nor between body length (Ls) and intensity of infestation, in all three host species.
\end{abstract}

Foram analisados 446 peixes: 190 Pygocentrus nattereri, 193 Serrasalmus maculatus e 63 S. marginatus, capturados nas baías Caiçara superior e inferior na bacia do alto rio Paraguai, durante um ciclo hidrológico nos meses de maio de 2008 a abril de 2009. Foram encontradas seis espécies de Branchiura: Dolops bidentata, D. longicauda, Dolops sp., Argulus multicolor, A. chicomendesi e Dipteropeltis hirundo. Todos os peixes estavam parasitados por mais de uma espécie de Branchiura e a prevalência geral foi $33,4 \%$. As prevalências foram: P. nattereri $52,6 \%$, S. maculatus $20,3 \%$ e S. marginatus $15,8 \%$. O fator de condição relativo $(\mathrm{Kn})$ diferiu significativamente entre indivíduos parasitados e não parasitados apenas em $P$. nattereri e $S$. maculatus. Não houve correlação significativa entre Kn e abundância de parasitos, nem entre comprimento padrão (Ls) e intensidade de infestação, nas três espécies de piranhas analisadas.

Key words: Argulus, Dolops, Pygocentrus, Relative condition factor, Serrasalmus.

\section{Introduction}

One of the main challenges of ecology is to clarify the role of parasites in the host's population dynamics (Begon et al., 2007). The relationship between fish and parasites in the natural environment is an important tool for the understanding of pathologies occurring in hosts, and are also relevant to pisciculture (Tavares-Dias et al., 2000). Aquatic environments facilitate reproduction, dispersion and survival of parasitic organisms (Malta, 1984). Direct effects, such as host impairment, can induce indirect consequences such as reduction in foraging rate (Crowden \& Broom, 1980; Milinski, 1984), greater vulnerability to predators (Arme \& Owen, 1967) and decreased resistance to environmental stress (Lewis \& Hettler, 1968). The relative condition factor $(\mathrm{Kn})$ is a quantitative indicator of fish well-being, therefore the analysis of its variability between populations and individuals can show the effects of parasitisation (Ranzani-Paiva et al., 2000). Many studies on the biology of endoparasites have been conducted in Osteichthyes. However, little information is available on the infestation levels and modes of transmission of crustacean ectoparasites in natural conditions (Szalai \& Dick, 1991). Most studies on branchiuran crustacean ectoparasites

\footnotetext{
${ }^{1}$ Universidade Federal de Mato Grosso, Programa de Pós-Graduação em Ecologia e Conservação da Biodiversidade, Instituto de Biociências. Av. Fernando Correa da Costa, s/nº, Bairro Boa Esperança, 78060-900 Cuiabá, MT, Brazil. marcio_fontana@hotmail.com

${ }^{2}$ Universidade Estadual de Maringá, Núcleo de Pesquisas em Limnologia, Ictiologia e Aquicultura, Laboratório de Ictioparasitologia. Av. Colombo, 5790, Bloco G-90, sala 11, 87020-900 Maringá, PR, Brazil. takemotorm@nupelia.uem.br

${ }_{3}^{3}$ Instituto Nacional de Pesquisas da Amazônia - INPA, Laboratório de Parasitologia de Peixes, Cx. Postal 478, 69011-970 Manaus, Amazonas, Brazil.jcmalta@inpa.gov.br

${ }^{4}$ Universidade Federal de Mato Grosso, Laboratório de Ecologia e Manejo de Recursos Pesqueiros, Instituto de Biociências. Av. Fernando Correa da Costa, s/nº, Bairro Boa Esperança, 78060-900 Cuiabá, MT, Brazil.1mateus@ufmt.br
} 
published in South America are related to taxonomy (Malta, 1982a; Tanaka, 2000). The Branchiura is a small group of ectoparasites, comprising a single family (Argulidae), with only four genera, i.e., Argulus, Dolops, Dipteropeltis, and Chonopeltis. Are commonly known as fish lice and are characterized by their dorsoventrally flattened bodies, which are covered by a horseshoeshaped dorsal cephalic shield formed by the carapace lobes. Its posterolateral lobes extend over the four pairs of thoracic biramous legs to a greater or lesser extend depending on the species. Five pairs of cephalic appendages occur ventrally, i.e., antennulae (absent or reduced in Chonopeltis), antennae, mandibles, maxillulae, and maxillae. The antennulae bear a small hook terminally. There are approximately 210 species (Moller $e t$ al., 2007). They are all parasites of fishes but on rare occasion have been reported from alligators (Ringuelet, 1943), tadpoles (Stuhlmann, 1891; Wolfe et al., 2001), and salamanders (Poly, 2003). Dipteropeltis was described in 1912 (Calman, 1912) and since its description, a limited number of reports appeared sporadically. Information on this genus is therefore very limited. The adults range between 5 and $15 \mathrm{~mm}$ in size although Dipteropeltis may reach up to $30 \mathrm{~mm}$ (Piasecki \& Oldewage, 1992).The transmission is direct and the parasites actively swim to find a host in which they will be fixed to its body surface (Malta \& Varella, 1983).The fish ectoparasites Branchiura (Crustacea) display two different ways of attachment to the fish surface as adults: the first maxillae are either hooks (Dolops) or suction discs (Argulus, Chonopeltis, and Dipteropeltis) (Moller et al., 2008). According to Piasecki \& Oldewage (1992), the maxillulae are transformed into powerful suckers in the adults and are utilized to attach to their hosts except in Dolops, where the maxillulae bear strong hooks that penetrate the host for attachment. In general, the infestation results in ulcerous lesions that allow secondary infections by fungi, viruses, and bacteria (Thatcher, 2006). Species of Serrasalmidae are among the main predators that thrive in Neotropical freshwater ecosystems (Almeida et al., 1998). Piranhas represent a large percentage of the number of individuals and the total biomass of Osteichthyes where they live (Mago-Leccia, 1970). Because of that, many studies have been conducted on the interaction between piranhas and their crustacean ectoparasites (Malta, 1982b; Malta \& Varella, 1983; Carvalho et al., 2003). The aim of this study is to assess parasitism by argulids in Pygocentrus nattereri Kner, 1858, Serrasalmus maculatus Kner, 1858 and Serrasalmus marginatus Valenciennes, 1837, in two bays, upper and lower Caiçara, in the upper Paraguay river basin, in Pantanal, Mato Grosso State, Brazil, during one hydrological cycle from May 2008 to April 2009.

\section{Material and Methods}

\section{Study site}

Located in western Brazil, the Pantanal is the largest continuous freshwater floodplain in the world (Silva \& Abdon, 1998). Collections were made in the upper Paraguay River basin, Northern Pantanal, Cáceres municipality, Mato Grosso State, Brazil. Two bays were sampled: upper Caiçara Bay (UCB) and lower Caiçara Bay (LCB), located on the south east bank of the Paraguay River, between coordinates $16^{\circ} 05^{\prime} 02.8^{\prime \prime} \mathrm{S}$ $57^{\circ} 44^{\prime} 22.7^{\prime \prime} \mathrm{W}$ and $16^{\circ} 06^{\prime} 41.9^{\prime \prime} \mathrm{S} 57^{\circ} 45^{\prime} 14.6^{\prime \prime} \mathrm{W}$ (Fig. 1).

\section{Sampling and data analysis}

Monthly collections were performed during a hydrological cycle from May 2008 to April 2009. Collections were made only during the day and the piranhas were captured in six different points (UCB: P1, P2, P3; LCB: P4, P5, P6) and in two microhabitats: margin and middle, of both bays (Fig.1). Weight, standard length and gender of the hosts were recorded. Necropsy of the hosts, collection, conservation and preparation of ectoparasites were performed according to the method of Malta (1982a). The standard length (Ls) and total weight (Wt) of each host were adjusted to the $\mathrm{Wt} / \mathrm{Ls}$ relationship curve $\left(\mathrm{Wt}=\mathrm{a} \cdot \mathrm{Lt}^{\mathrm{b}}\right)$, given the estimated values of the regression coefficients $\mathrm{a}$ and $\mathrm{b}$. The variables $a$ and $b$ were used to estimate the expected weight (We), using the equation: $\mathrm{We}=\mathrm{a} \cdot \mathrm{Lt}^{\mathrm{b}}$. The relative condition factor $(\mathrm{Kn})$ was calculated, according to the quotient between observed weight and expected weight for a given length $(\mathrm{Kn}=\mathrm{Wt} / \mathrm{We})(\mathrm{Le}$ Cren, 1951). The MannWhitney test (U) was used to determine differences in $\mathrm{Kn}$ between parasitized and non-parasitized (Zar, 1996). To eliminate the interference of gonadal weight on the $\mathrm{Kn}$, the infected and uninfected hosts were divided into two groups: maturematuration and rest-depleted-immature.Spearman's rank correlation coefficient (rs) was used to assess possible correlations between $\mathrm{Kn}$ and intensity of infestation, as well as intensity of infestation and host length (Zar, 1996). The KruskalWallis test $(\mathrm{H})$ was applied to compare mean intensity values of branchiuran species between hosts. In order to compare the

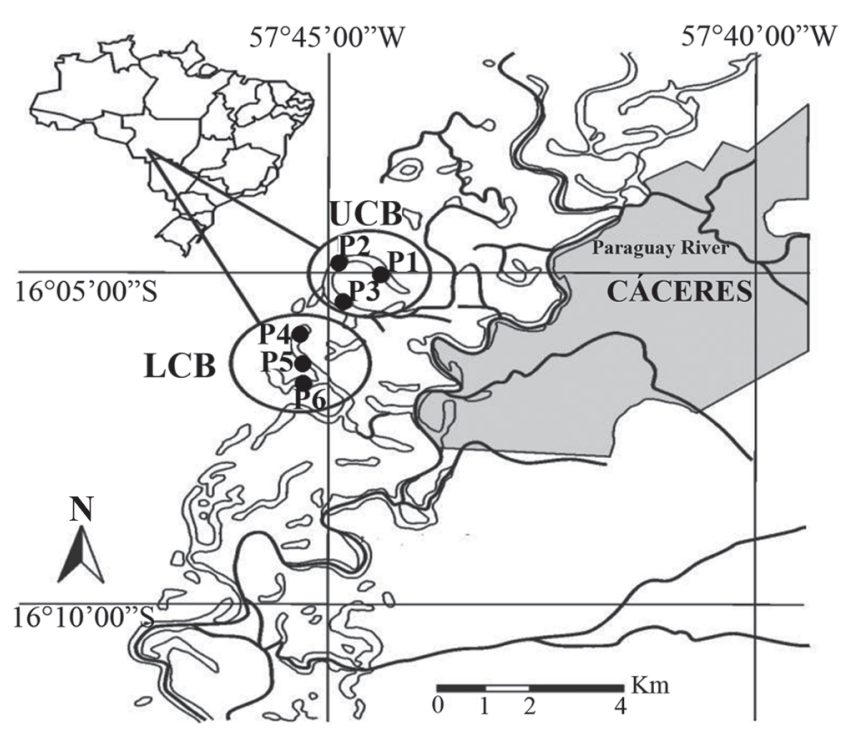

Fig. 1. Location of collection sites in the upper Caiçara bay (UCB - Points 1, 2 and 3) and lower Caiçara bay (LCB - Points 4, 5 and 6), upper Paraguay River basin, Pantanal, Mato Grosso, Brazil. 
frequency of branchiuran species according to attachment sites on hosts, the Independence Test of Chi-square $\left(\chi^{2}\right)$ was used on the data in a contingency table. The statistical significance level adopted was 0.05 . The prevalence, mean intensity, abundance and amplitude of infestation concepts were used according to Bush et al. (1997). Voucher specimens of hosts were deposited in the Fish Collection at the Departamento de Biologia e Zoologia of the Universidade Federal do Mato Grosso (Serrasalmus maculatus, CPUFMT 686; Pygocentrus nattereri, CPUFMT 687 / CPUFMT 688; and Serrasalmus marginatus, CPUFMT 689). The Branchiura voucher specimens are in the Collection of non-insect Invertebrates of the Instituto Nacional de Pesquisas da Amazônia (Dipteropeltis hirundo, INPA 1873; Dolops longicauda, INPA1956; Dolops bidentata, INPA1957; Dolops sp., INPA1958; Argulus multicolor, INPA1959 / INPA1960 / INPA1962; and Argulus chicomendesi, INPA1961).

\section{Results}

In total, 190 individuals of Pygocentrus nattereri were captured $($ male $=128$; female $=62), 193$ of Serrasalmus maculatus $($ male $=84$; female $=109)$ and 63 of $S$. marginatus (male $=37$; female $=26)$. Six Branchiura species were recorded: Dolops bidentata (Bouvier, 1899), D. longicauda (Heller, 1857), Dolops sp., Dipteropeltis hirundo Calman, 1912, Argulus multicolor Stekhoven, 1937 and A. chicomendesi Malta \& Varella, 2000. Dolops longicauda and $D$. hirundo occurred only once on $S$. maculatus. Dolops bidentata showed the highest prevalence in P. nattereri (male and female) during drought (April-September) and the rainy season (October-March), in two bays. A. multicolor and $A$. chicomendesi had the lowest prevalence during the dry period and did not occur during the rainy season, in two bays. The prevalence rates of infestation are shown in Table1.

During the study period, in dry season, there was a greater mean intensity infestation and abundance by Dolops bidentata on Pygocentrus nattereri (male and female). The lowest values were recorded by Argulus multicolor and A. chicomendesi on three host species. No specimen from A. multicolor was found parasitizing $S$. maculatus (male and female), in this climatic station. (Table 2.). In the rainy season there was no record of any specimen of A. multicolor and A. chicomendesi in males and females for the three host species. During the rainy season one specimen of D. bidentata and one Dolops sp. parasitizing $S$. marginatus were found. Parasitological rates of the
Branchiura species parasitizing P. nattereri, S. maculatus, and $S$. marginatus (male and female) are shown in Table 3.

In the dry climatic station, the average rate of oxygen dissolved in water was $6.4 \mathrm{mg} / 1$ (range: $4.64-7.84 \mathrm{mg} / 1$ ) and the rainy season the average was $3.5 \mathrm{mg} / 1$ (range: $0.94-5.62$ $\mathrm{mg} / \mathrm{l})$. There was a significant difference between $\mathrm{Kn}$ of parasitized and non-parasitized $P$. natterer $i(\mathrm{Z}[\mathrm{U}]=1.72 ; \mathrm{p}=$ $0.042)$ and $S$. maculatus $(Z[U]=8.08 ; \mathrm{p}=0.001)$. There was no significant difference in $S$. marginatus $(\mathrm{Z}[\mathrm{U}]=0.02 ; \mathrm{p}=$ 0.492) (Fig. 2).

In addition, there was no strong relationship between $\mathrm{Kn}$ and infestation intensity by Branchiura in all three piranha species (P. nattereri: $\mathrm{rs}=0.152 ; \mathrm{p}=0.129$, S. maculatus: $\mathrm{rs}=$ $0.19 ; \mathrm{p}=0.231$ and $S$. marginatus: $\mathrm{rs}=0.52 ; \mathrm{p}=0.121)$. The correlation between the length of hosts and infestation intensity by Branchiura was not significant $(P$. nattereri: $\mathrm{rs}=$ -0.0313 and $\mathrm{p}=0.62 ;$ S. maculatus: $\mathrm{rs}=-0.060$ and $\mathrm{p}=0.64 ; S$. marginatus: $\mathrm{rs}=0.286$ and $\mathrm{p}=0.21)$ (Fig. 3 ).

The Kruskal-Wallis test $(\mathrm{H})$ did not show significant differences in the mean intensity values between Branchiura species and host species $(H=6.6 ; p=0.085)$. However, the frequency of species of Branchiura attached in different sites of hosts showed considerable variation $\left(\chi^{2}=27.62 ; p=0.0062\right)$. The highest infestation rate was recorded in the peri-opercular region, pectoral and pelvic fins.

\section{Discussion}

Branchiura are fish ectoparasites. They attach themselves to the body surface, fin base, branchial and mouth cavities of their hosts (Castro, 1950; Yamaguti, 1963; Malta, 1982a, b). Attachment to the host is facilitated by suckers or hooks on the maxillulae as well as the hooks on the antennulae (Piasecki \& Oldewage, 1992).In this study, six Branchiura species: Dolops bidentata, D. longicauda, Dolops sp., Argulus multicolor, A. chicomendesi, and D. hirundo, were recorded for the first time parasitizing three species of piranhas, Pygocentrus nattereri, Serrasalmus maculatus and $S$. marginatus captured in the upper Paraguay river. Dolops longicauda was not considered for statistical purposes because there was only one specimen (female, whose body was full of eggs). The first record of D. longicauda in the Paraguay River was near Cáceres (Moreira, 1913). Dolops bidentata was first reported in the Cuiabá River (Silva-Souza

Table 1. Prevalence (\%) of Branchiura species parasitizing Pygocentrus nattereri, Serrasalmus maculatus, and Serrasalmus marginatu captured in the Caiçara bays, upper Paraguay River basin, Pantanal, Mato Grosso, Brazil, from May 2008 to April 2009.

\begin{tabular}{|c|c|c|c|c|c|c|c|}
\hline \multirow{3}{*}{ Weather station } & \multirow{3}{*}{ Parasite/ Host } & \multicolumn{6}{|c|}{ Prevalence (\%) } \\
\hline & & \multicolumn{2}{|c|}{ P. nattereri } & \multicolumn{2}{|c|}{ S. maculatus } & \multicolumn{2}{|c|}{ S. marginatus } \\
\hline & & male & female & male & female & male & female \\
\hline Dry & D. bidentata & 56.5 & 35.7 & 26.5 & 23.3 & 18.2 & 0.0 \\
\hline \multirow[t]{3}{*}{ (April-September) } & Dolops sp. & 27.1 & 10.7 & 16.3 & 6.7 & 9.1 & 25.0 \\
\hline & A. multicolor & 1.2 & 7.1 & 0.0 & 3.3 & 4.5 & 0.0 \\
\hline & A. chicomendesi & 1.2 & 0.0 & 0.0 & 0.0 & 4.5 & 0.0 \\
\hline Rainfall & D. bidentata & 20.9 & 50.0 & 2.9 & 7.6 & 0.0 & 9.1 \\
\hline (October-March) & Dolops sp & 11.6 & 11.8 & 5.7 & 5.1 & 0.0 & 4.5 \\
\hline
\end{tabular}


Table 2. Parasitological rates of the Branchiura species parasitizing Pygocentrus nattereri, Serrasalmus maculatus, and Serrasalmus marginatus captured in the Caiçara bays, upper Paraguay River basin, Pantanal, Mato Grosso, Brazil, during dry season (April to September 2008). $\mathrm{MI}=$ mean intensity; $\mathrm{SD}=$ Standard deviation; Amp = amplitude; MA = mean abundance.

\begin{tabular}{|c|c|c|c|c|c|c|c|}
\hline \multirow{3}{*}{\multicolumn{2}{|c|}{$\begin{array}{l}\text { Weather station } \\
\text { Host/ Parasites }\end{array}$}} & \multicolumn{6}{|c|}{ Dry } \\
\hline & & \multicolumn{3}{|c|}{ male } & \multicolumn{3}{|c|}{ female } \\
\hline & & $\mathrm{MI} \pm \mathrm{SD}$ & $\mathrm{MA} \pm \mathrm{SD}$ & Amp & $\mathrm{MI} \pm \mathrm{SD}$ & $\mathrm{MA} \pm \mathrm{SD}$ & Amp \\
\hline \multicolumn{8}{|c|}{ P. nattereri } \\
\hline & D. bidentata & $3.6 \pm 3.3$ & $2.10 \pm 2.8$ & $1-22$ & $1.7 \pm 0.7$ & $0.60 \pm 0.6$ & $1-3$ \\
\hline & Dolops sp. & $1.4 \pm 0.5$ & $1.00 \pm 0.3$ & $1-3$ & $1.0 \pm 0.0$ & $0.10 \pm 0.0$ & 1 \\
\hline & A. multicolor & $3.0 \pm 0.0$ & $0.04 \pm 0.0$ & $1-3$ & & - & - \\
\hline & A. chicomendesi & $1.0 \pm 0.0$ & $0.01 \pm 0.0$ & 1 & $1.0 \pm 0.0$ & $0.10 \pm 0.0$ & 1 \\
\hline \multicolumn{8}{|l|}{$\overline{\text { S. maculatus }}$} \\
\hline & D. bidentata & $2.8 \pm 1.6$ & $0.80 \pm 1.1$ & $1-6$ & $2.3 \pm 1.3$ & $0.50 \pm 0.8$ & $1-5$ \\
\hline & Dolops sp. & $1.3 \pm 0.3$ & $0.20 \pm 0.2$ & $1-2$ & $2.0 \pm 1.4$ & $0.10 \pm 0.5$ & $1-3$ \\
\hline & A. chicomendesi & - & - & - & $1.0 \pm 0.0$ & $0.03 \pm 0.0$ & 1 \\
\hline \multicolumn{8}{|c|}{ S. marginatus } \\
\hline & D. bidentata & $1.8 \pm 0.5$ & $0.30 \pm 0.3$ & $1-2$ & - & - & - \\
\hline & Dolops sp. & $1.0 \pm 0.0$ & $0.10 \pm 0.2$ & 1 & $1.0 \pm 0.0$ & $0.30 \pm 0.0$ & 1 \\
\hline & A. multicolor & $1.0 \pm 0.0$ & $0.05 \pm 0.0$ & 1 & - & - & - \\
\hline & A. chicomendesi & $1.0 \pm 0.0$ & $0.05 \pm 0.0$ & 1 & - & - & - \\
\hline
\end{tabular}

et al., 2011). Dolops hirundo was first recorded in the Miranda and Abobral rivers, Pantanal of Mato Grosso do Sul (Carvalho et al., 2003) and was found in the Lower Caiçara Bay in only one sample (female, without eggs in the thorax), being insufficient in number for further exploration of the species. Argulus multicolor was recorded in the Kuluene and Xingu rivers in Mato Grosso state (Castro, 1949). Argulus chicomendesi was first collected in Janauacá Lake, on the southeast bank of the Solimões River bank in Amazonas state (Malta \& Varella, 2000). Also in this study, it was recorded for the first time $A$. chicomendesi parasitizing fish in Mato Grosso state.The infestation showed a seasonal pattern with a high prevalence of D. bidentata and Dolops sp. in the dry season (April-September) on P. nattereri and S. maculatus. This occurred when ideal conditions prevailed with high dissolved oxygen concentrations in the water and when hosts species were more abundant. There was no synchronization between the reproductive period of hosts. Reproduction of piranhas occurred during the rainy station and Branchiura in the dry

Table 3. Parasitological rates of the Branchiura species parasitizing Pygocentrus nattereri, Serrasalmus maculatus and Serrasalmus marginatus captured in the Caiçara bays, upper Paraguay River basin, Pantanal, Mato Grosso, Brazil, during rainfall season (October 2008 to March 2009). MI=mean intensity; $\mathrm{SD}=$ Standard deviation; Amp=amplitude; $\mathrm{MA}=$ mean abundance.

\begin{tabular}{|c|c|c|c|c|c|c|}
\hline \multirow{3}{*}{$\begin{array}{c}\text { Weather station } \\
\text { Host/ } \\
\text { Parasites }\end{array}$} & \multicolumn{6}{|c|}{ Rainfall } \\
\hline & \multicolumn{3}{|c|}{ male } & \multicolumn{3}{|c|}{ female } \\
\hline & $\overline{\mathrm{MI}} \pm \mathrm{SD}$ & $\mathrm{MA} \pm \mathrm{SD}$ & Amp & $\mathrm{MI} \pm \mathrm{SD}$ & $\mathrm{MA} \pm \mathrm{SD}$ & Amp \\
\hline \multicolumn{7}{|l|}{ P. nattereri } \\
\hline D. bidentata & $1.7 \pm 0.8$ & $0.30 \pm 0.5$ & $1-4$ & $2.1 \pm 0.9$ & $1.00 \pm 0.7$ & $1-4$ \\
\hline Dolops sp. & $1.2 \pm 0.3$ & $0.10 \pm 0.1$ & $1-2$ & $1.0 \pm 0.0$ & $1.00 \pm 0.0$ & 1 \\
\hline \multicolumn{7}{|l|}{ S. maculatus } \\
\hline D. bidentata & $1.0 \pm 0.0$ & $0.03 \pm 0.0$ & 1 & $2.3 \pm 1.2$ & $0.20 \pm 0.5$ & $1-4$ \\
\hline Dolops sp. & $1.0 \pm 0.6$ & $0.10 \pm 0.2$ & $1-2$ & $1.8 \pm 0.6$ & $0.10 \pm 0.2$ & $1-3$ \\
\hline
\end{tabular}

station. One factor likely to affect the dynamics of infestation for Branchiura in hosts may be the reproductive hormonal influence. Thomas (1964) and Pennycuick (1971) suggested that the low incidence of parasites during the spawning fish, which coincided with the period of rainfall, may be due to the presence of estrogen, a hormone that appears in the blood of the fish during maturation. After spawning, this hormone decreases, and the opposite effect happens. In the same context, William (1965) noted that Calicotyle kroyeri (Trematoda: Monogenea) was never present in pregnant Raja radiata (Rajiformes: Rajidae), while the non-pregnant females showed this parasite. Is it speculated that with the decrease of water in the bays concentrated the host and therefore increased habitat availability (host body) for attaching Branchiura. Poor health, decreased reproductive efficiency

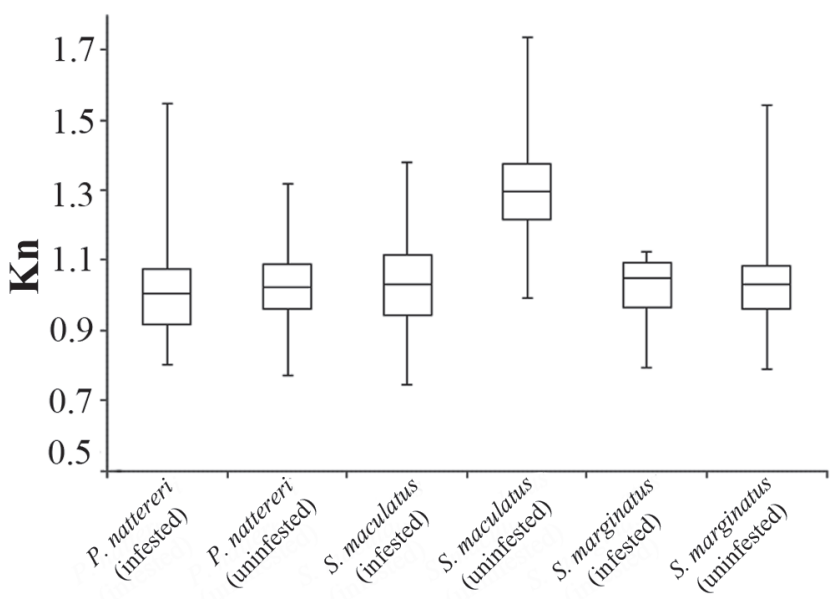

Fig. 2. Box-plot of Kn values in parasitized and non-parasitized individuals of Pygocentrus nattereri, Serrasalmus maculatus and Serrasalmus marginatus captured in the upper and lower Caiçara bays, upper Paraguay River basin, Pantanal, Mato Grosso, Brazil. 

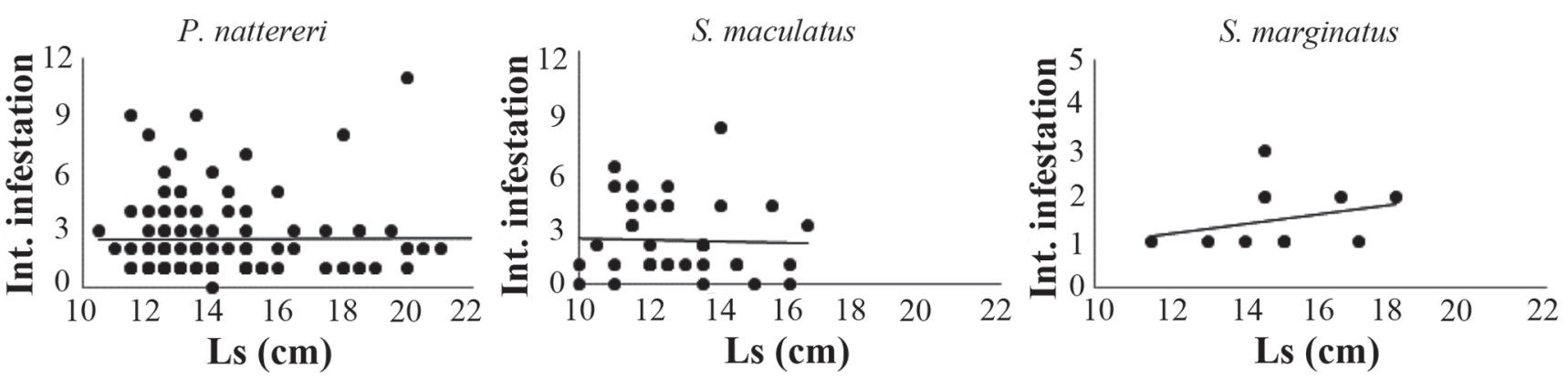

Fig. 3. Correlation between Standard length (Ls) and intensity (Int.) of infestation in Pygocentrus nattereri, Serrasalmus maculatus, and Serrasalmus marginatus captured in the upper and lower Caiçara bays, upper Paraguay River basin, Pantanal, Mato Grosso, Brazil.

and feeding conversion are among the negative effects on hosts (Bauer, 1961). However, the effects that pathogenic agents have on fish are difficult to assess or quantify, especially in natural conditions (Chubb, 1973). According to Le Cren (1951), the condition factor is a quantitative indicator of fish fitness, reflecting recent feeding conditions and is obtained using the weight-length relation of the individual. According to Brasil-Sato \& Pavanelli (1999) and Lizama et al. (2006), the relative condition factor can be used as a tool for studies of the relationship between the host's health and level of parasitism. In this study Pygocentrus nattereri and Serrasalmus maculatus show significant differences in condition factor between parasitized and non-parasitized fish. However, S. marginatus (parasited or not) showed better body condition compared to P. nattereri and S. maculatus, suggesting better adaptation to the actions of Branchiura species. Normally endoparasites reach their hosts through feeding, while ectoparasites find a host through their ability to swim during their juvenile stages or through their close proximity to their hosts (Begon et al., 2007). For many organisms, life in groups can be an advantage, reducing predation risk and improving foraging capacity (Wilson, 2000). However, there is greater risk of exposure to parasites given the close proximity of individuals (Alcock, 2001).This is especially true for fishes that swim in schools (Poulin, 1991). In the Cuiabá River, in the Pantanal of Mato Grosso, a study was carried out using underwater observations. The authors registered $P$. nattereri swimming in schools of 20 to 30 individuals and $S$. spilopleura (= Serrasalmus maculatus in Paraguay River) in schools of up to 20 fish (Sazima \& Machado, 1990). Pygocentrus nattereri and S. spilopleura (= Serrasalmus maculatus in Paraguay River) are sympatric species (Behr \& Signor, 2008). The gregarious or solitary behaviors were the main factors determining the structure of the parasites infra-communities in $S$. spilopleura (= Serrasalmus maculatus in Paraguay River), a gregarious species, and S. marginatus, a non-gregarious species (Tanaka, 2000). Gregarious habits, size of schools and sympatry are facilitating factors in parasitic transmission of ectoparasites in fish with gregarious behavior. These factors may help to explain the highest incidences of branchiuran species in $P$. nattereri and S. maculatus. Serrasalmus marginatus is a territorial species and patrols feeding sites in areas of 3 to 4 $\mathrm{m}^{2}$ (Sazima \& Machado, 1990). They show lower prevalence, possibly due to the fact that they do not show gregarious behavior and are territorials. In addition, some ectoparasite species are found in greater quantities on larger fish. This indicates that the parasite burden can vary in proportion related to the age and size of the hosts, given the longer exposure period and larger surface area for parasitic aggregation (Cloutman \& Becker, 1977; Hanek \& Fernando, 1978; Poulin, 1991). In P. nattereri, S. spilopleura (= Serrasalmus maculatus in Paraguay River) and $S$. marginatus captured in Miranda River, Pantanal of Mato Grosso do Sul, the correlation between body length and the incidence of ectoparasites was not significant (Carvalho et al., 2003). Avenant \& Van As (1985) reported that the occurrence of Dolops ranarun is linked to the distribution of the two major hosts, Oreochromis mossambicus (Perciformes: Cichlidae) and Clarias gariepinus (Siluriformes: Clariidae). In this study, the correlation between size of the fish and intensity of infestation was not significant in fish from the UCB and LCB. Parasitic species generally select special microhabitats or tissues to attach to, suggesting a wide opportunity of differentiation of niches (Begon et al., 2007). The transmission of argulids is direct since they actively swim to find a host to attach to. They can leave the host at any time and move to another fish. They can also slide over the surface of the fish in order to find an appropriate site for feeding (Thatcher, 2006). The largest number of branchiuran individuals was found in the ventral body area of P. nattereri (Sazima \& Machado, 1990). In this study, the cranio-ventral area (gullet region which incorporates pectoral and pelvic fins) and the peri-opercular area were the sites where most Branchiura occurred in the three host species. Barnard (1955) reported the presence of Dolops ranarum in the mouth cavity and gill chamber of $O$. mossambicus. Analysis of attachment site preference of crustacean ectoparasites was carried out by Bulow et al. (1979) for the copepod Lernaea cyprinacea Linnaeus on stream fish. These authors divided the body into different regions and 
found that L. cyprinacea preferred sheltered areas for attachment. Kruger et al. (1983) investigated site selection of the branchiuran Argulus japonicus and also divided the body into different regions. These authors did not find any distinct pattern as to site selection on the body of host fish. Avenant \& Van As (1985) evaluated the preference of attachment site of D. ranarum from information collected at various localities during winter, spring and summer and no significant pattern related to location or season could be observed concerning site selection on any of different host fish. According to Fryer (1968), D. ranarum shows a distinct preference for the buccal cavity and its extensions on scaled fish, but is also found on the skin of smooth-skinned fish. This study demonstrates that behavior of the hosts can influence, directly or indirectly, the structure of Branchiura community. However, it is still important to assess if reproductive factors, as well as environmental factors controlling changes in flooding basin of the Paraguay River, also influence host-parasite relationships.

\section{Acknowledgements}

The authors would like to thank Jansen Zuanon (INPA) for the taxonomic identification of host fishes.

\section{Literature Cited}

Alcock, J. 2001. Animal Behavior: An Evolutionary Approach. Maryland, Sinauer Associates, 543p.

Almeida, V. L. L., N. S. Hahn \& C. S. Agostinho. 1998. Stomach content of juvenile and adult piranhas (Serrasalmus marginatus) in the Paraná Floodplains, Brazil. Studies on Neotropical Fauna and Environment, 33: 100-105.

Arme, C. \& R. W. Owen, 1967. Infections of the three-spined stickleback, Gasterosteous aculeatus L. with the plerocercoid larvae of Schistocephalus solidus (Muller, 1776), with special reference to pathological effects. Parasitology, 57: 301-314.

Avenant, A. \& J. G. Van As. 1985.Occurrence and distribution of Dolops ranarum Stuhlmann, ectoparasite of freshwater fish in the Transvaal, South Africa. Journal Fish Biology, 27: 403-416.

Barnard, K. H. 1955. South African parasitic Copepoda. Annals of the South African Museum, 41: 223-312.

Bauer, O. N. 1961. Relationships between host fishes and their parasites. Pp. 84-103. In: Dogiel ,V. A., G. K. Petrushevski \& Y. I. Polyanski (Eds.). Parasitology of fishes. Edinburgh, Leningrad University Press, 384p.

Begon, M., C. R. Townsend \& J. L. Harper. 2007. Parasitismo e doença. Pp. 347-380. In: Begon, M., C. R. Townsend \& J. L. Harper (Eds.). Ecologia de Indivíduos a Ecossistemas. Porto Alegre, Artmed, 740p.

Behr, E. R. \& C. A. Signor. 2008. Distribuição e alimentação de duas espécies simpátricas de piranhas Serrasalmus maculatus e Pygocentrus nattereri (Characidae: Serrasalminae) do rio Ibicuí, Rio Grande do Sul, Brasil. Iheringia, 98: 501-507.

Brasil-Sato, M. C. \& G. C. Pavanelli. 1999. Ecological and reproductive aspects of Neoechinorhynchus pimelodi (Eoacantocephala, Neoechinorhynchidae) of Pimelodus maculatus Lacépède (Siluroidei, Pimelodidae) of the São Francisco River, Brazil. Revista Basileira de Zoologia, 16: 73-82.
Bulow, F. J., Winningham, J. R. \& Hooper, R. C. 1979. Occurrence of the copepod parasite Lernaea cyprinacea in a stream fish population. Transactions of the American Fisheries Society, 108: 100-102.

Bush, A. O., K. D. Lafferty, J. M. Lotz \& A. W. Shostak. 1997. Parasitology meets ecology on its own terms. Journal of Parasitology, 84: 575-583.

Carvalho, L. N., K. Del-Claro \& R. M.Takemoto. 2003. Host-parasite interaction between branchiurans (Crustacea: Argulidae) and piranhas (Osteichthyes: Serrasalminae) in the Pantanal wetland of Brazil. Environmental Biology of Fishes, 67: 289-296.

Calman, W. T. 1912. On Dipteropeltis a new genus of the crustacean Order Branchiura. Proceedings of the Zoological Society of London, 4: 763-766.

Castro, A. L. 1949. Contribuição ao conhecimento dos crustáceos argulídeos do Brasil (Branchiura: Argulidae) com descrição de uma nova espécie. Boletim do Museu Nacional. Nova Série: Zoologia, 93: 1-8.

Castro, A. L. 1950. Contribuição ao conhecimento dos argulídeos do Brasil. Descrição de duas novas espécies. Academia Brasileira de Ciências, 22: 245-255.

Chubb, J. C. 1973. Influence of parasites on freshwater fishes in Britain. Verhandlungen der Internationalen Vereinigung für Theoretische und Angewandte Limnologie, 18: 1628-1632.

Cloutman, D. G. \& D. A. Becker. 1977. Some ecological aspects of Ergasilus centrarchidarum Wright (Crustacea: Copepoda) on largemouth and spotted bass in Lake Fort Smith. Journal Parasitology, 63: 372-376.

Crowden, A. E. \& D. M. Broom. 1980. Effects of the eyefluke, Diplostomum spathaceum, on the behaviour of dace (Leuciscus leuciscus). Animal Behaviour, 28: 287-294.

Fryer, G. 1968. The parasitic Crustacea of African freshwater fishes; their biology and distribution. Journal of Zoology London, 156: 45-95.

Hanek, G. \& C. H. Fernando. 1978. The role of season, habitat, host age and sex on gill parasites of Lepomis gibbosus (L). Canadian Journal Zoology, 56: 1247-1250.

Kruger, I., Van As, J. G. \& Saayman, J. E. 1983. Observations on the occurrence of the fish lice Argulus japonicus Thiele, 1990 in the western Transvaal. South African Journal of Zoology, 18: 408-410.

Le Cren, E. D. 1951. The length-weight relationship and seasonal cycle in gonad weight and condition in the perch Perca fluviatilis. Journal of Animal Ecology, 20: 201-219.

Lewis, R. M. \& W. F. Hettler. 1968. Effects of temperature and salinity on the survival of young Atrantic menhaden, Brevoortia tyrannus. American Fisheries Society, 97: 344-349.

Lizama, M. de Los A. P., R. M. Takemoto \& G. C. Pavanelli. 2006. Parasitism influence on the hepato, splenosomatic and weight/ lenght relation and relative condition factor of Prochilodus lineatus (Valenciennes, 1836) (Prochilodontidae) of the upper Paraná river floodplain, Brazil. Revista Brasileira de Parasitologia Veterinária, 15: 116-122.

Mago-Leccia, F. 1970. Estudios preliminares sobre la ecología de los peces de los llanos. Acta Biológica, 7: 71-102.

Malta, J. C. O. 1982a. Os argulídeos (Crustacea: Branchiura) da Amazônia Brasileira. Aspectos da ecologia de Dolops discoidalis Bouvier, 1899 e Dolops bidentata Bouvier, 1899. Acta Amazonica, 12: 521-528.

Malta, J. C. O. 1982b. Os argulídeos (Crustacea: Branchiura) da Amazônia Brasileira, 2. Aspectos da ecologia de Dolops geagy Bouvier, 1897 e Argulus juparanaensis Castro, 1950. Acta Amazonica, 12: 701-705. 
Malta, J. C. O. 1984. Os Peixes de um lago de várzea da Amazônia Central (Lago Janauacá, Rio Solimões) e suas relações com os crustáceos ectoparasitos (Branchiura: Argulidae). Acta Amazonica, 14: 355-372.

Malta, J. C. O. \& A. M. B. Varella. 1983. Os argulídeos (Crustacea: Branchiura) da Amazônia Brasileira 3. Aspectos da ecologia de Dolops striata Bouvier, 1899 e Dolops carvalhoi Castro, 1949. Acta Amazonica, 13: 299-306.

Malta, J. C. O. \& A. M. B. Varella. 2000. Argulus chicomendesi sp. n. (Crustacea: Argulidae) parasita de peixes da Amazônia brasileira. Acta Amazonica, 30: 481-498.

Milinski, M. 1984. Parasites determine a predator's optimal feeding strategy. Behavioural Ecology and Sociobiology, 15: 35-37.

Moller, O. S., J. Olesen \& D. Waloszek. 2007. Swimming and cleaning in the free-swimming phase of Argulus larvae (Crustacea: Branchiura) - Appendage adaptation and functional morphology. Journal of Morphology, 268: 1-11.

Moller, O. S., J. Olsen, A. Avenant-Oldewage, P. F. Thomsen \& H. Glenner. 2008. First maxillae suction discs in Branchiura (Crustacea): Development and evolution in light of the first molecular phylogeny of Branchiura, Pestastomida, and other "Maxillopoda". Arthropod Structure \& Development, 37:333-346.

Moreira, C. 1913. Comissão de Linhas Telegraphicas Estratégicas de Matto-Grosso ao Amazonas: História Natural, Zoologia, Crustáceos. Papelaria Macedo, 5: 10-11.

Pennycuick, L. 1971. Quantitative effects of three species of parasites on a population of Three-spined sticklebacks, Gasterosteus aculeatus. London: Journal Zoology, 165: 143-162.

Piasecki, W. \& A. Avenant- Oldewage. 1992. Diseases Caused by Crustacea. Pp. 1162-1174. In: Schäperclaus, W. (Ed.). Fish Diseases (English translation of 'Fischkrankheiten', $5^{\text {th }}$ corrected and substantially enlarged edition 1986). A. A. Balkema, Rotterdam, 164p.

Poly, W. J. 2003. Argulus ambystoma, a new species parasitic on the salamander Ambystoma dumerilii from Mexico (Crustacea: Branchiura: Argulidae). Ohio Journal of Science, 103: 52-61.

Poulin, R. 1991. Group-living and the richness of the parasite fauna in Canadian freswater fishes. Oecologia, 3: 390-394.

Ranzani-Paiva, M. J. T., A. T. Silva-Souza, G. C. Pavanelli \& R. M. Takemoto. 2000. Hematological characteristics and relative condition factor (Kn) associated with parasitism in Schizodon borelli (Osteichthyes, Anostomidae) and Prochilodus lineatus (Ostheichtyes, Prochilodontidae) from Parana River, Porto Rico region, Parana, Brazil. Acta Scientiarum Biological Sciences, 22: 515-521.

Ringuelet, R. 1943. Revision de los Argúlidos Argentinos (Crustácea: Branchiura) com el catallogo de las espesies neotropicales. Revista del Museo de La Plata (Seccion Zoologia), 3: 43-99.
Sazima, I. \& F. A. Machado. 1990. Underwater observations of piranhas in western Brazil. Environmental Biology of Fishes, 28: 17-31.

Silva-Souza, A. T., V. D. Abdallah, R. K. de Azevedo, F. A. da Silva \& J. L. Luque. 2011. Expanded Description of Dolops bidentata (Bouvier, 1899) (Branchiura: Argulidae) based on specimens collected on Pygocentrus nattereri Kner, 1858 (Characiformes) from Poconé Wetland, MT, Brazil. Brazilian Journal of Biology, 71: 145-149.

Silva, J. S. V. \& M. M. Abdon. 1998. Delimitação do Pantanal Brasileiro e suas sub-regiões. Pesquisa Agropecuária Brasileira, 33: 1703-1711.

Stuhlmann, F. 1891. Zur kenntniss der Fauna central-afrikanischer Seen II. Ueber eine neue Art der Arguliden-Gattung Gyropeltis. Zoologische Jahrburcher, Abteilung für Systematik, 5: 152-154.

Szalai, A. J. \& T. A. Dick. 1991. Evaluation of gill nets, fyke nets, and mark-recapture methods to estimative the number of hirudinea and crustacea on fish. Journal of Parasitology, 77: 914-922.

Tanaka, L. K. 2000. Aspectos ecológicos dos parasitos de Serrasalmus marginatus Valenciennes, 1847 e Serrasalmus spilopleura Kner, 1860 (Characiformes, Serrasalmidae) do rio Baía, planície de inundação do alto rio Paraná. Unpublished MSc. Dissertation, Universidade Estadual de Maringá, Maringá, 32p.

Tavares-Dias, M., M. L. Martins \& F. L. Moraes. 2000. Condition factor, hepatosomatic and splenosomatic relation of freshwater fishes naturally parasitized. Acta Scientiarum Biological Sciences, 22: 533-537.

Thatcher, V. E. 2006. Amazon Fish Parasites. Branchiura. Pp. 391415. In: Thatcher, V. E. (Ed.). Amazon Fish Parasites. Bulgaria, Pensoft Publishers, 508p.

Thomas, J. D. 1964. A comparasion between the helminth burdens of male and female brown trout, Salmo trutta (L.) from a natural population in River Teify, West Wales. Parasitology, EUA:Cambridge University Press, 54: 263-272.

William, H. H. 1965. Observations on the occurrence of Dictyocotyle coelica and Calicotyle kroyeri (Trematoda: Monogenea). Parasitology, EUA: Cambridge University Press, 55:201-207.

Wilson, C. B. 2000. North American parasite copepods of the family Argulidae, with bibliography of the group and a systematic review of all know species. United State National Museum, 25: 625-742.

Wolfe, B. A., C. A. Harms, J. D. Groves \& M. R. Loomis. 2001. Treatment of Argulus sp. infestation of river frogs. Contemporary Topics in Laboratory Animal Science, 40: 35-36.

Yamaguti, S. 1963. Parasitic Copepoda and Branchiura of fishes. New York, Interscience Publishers, 1104p.

Zar, J. H. 1996. Biostatistical Analysis. New Jersey, Prentice-Hall, $662 \mathrm{p}$.

Submitted March 6, 2012

Accepted August 8, 2012

Published September 28, 2012 